\title{
Stakeholder Salience And Corporate Social Responsibility: Evidence From Three Companies
}

John D. Neill, (E-mail: john.neill@coba.acu.edu), Abilene Christian University O. Scott Stovall, (E-mail: scott.stovall@ coba.acu.edu), Abilene Christian University

\begin{abstract}
In this paper, we examine the corporate social responsibility (CSR) efforts of three socially conscious companies over time by employing Mitchell et al.'s (1997) stakeholder salience theory. Mitchell et al. maintain that the extent to which managers pay attention to the interests of various stakeholder groups is based on the power, legitimacy, and urgency of the claims of each group. Using these attributes of power, legitimacy, and urgency, we analyze how the CSR activities of Ben and Jerry's Ice Cream, Malden Mills, Inc., and Nova Chemicals Company have changed over time. Our investigation revealed that attributes of stakeholder salience shift over a firm's life cycle, and therefore levels of CSR activities change as well. For these firms, we found that power is the primary attribute of stakeholder salience driving CSR. That is, in order for a firm to engage in purposeful CSR activities, the stakeholder(s) pursuing a CSR agenda must possess the power to impose such an agenda on management. Based on the results of our analysis, we conclude that without power, legitimacy and urgency may not provide sufficient stakeholder salience to promote CSR activities.
\end{abstract}

\section{INTRODUCTION}

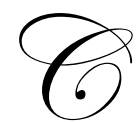

ertain corporations have a reputation for having a social mission, as well as a profit seeking mission. Such attempts at corporate social responsibility (CSR) appear to be counter cultural in this age in which stockholders are typically viewed as the dominant stakeholder group. In this paper, our goal is to examine the conditions under which active CSR agendas are able to be employed in a corporation and the extent to which such agendas are likely to change over time. In other words, we are concerned with how the level of CSR activities is likely to change over a firm's life cycle. In order to accomplish this task, we employ the stakeholder salience model developed by Mitchell et al. (1997) and apply it to three companies that have a tradition of being socially active. Mitchell et al. propose that the extent to which corporate managers pay attention to various stakeholder groups is based on the power, legitimacy, and urgency of the claims of each group. Using these attributes of power, legitimacy, and urgency, we examine how the CSR efforts of Ben and Jerry's Ice Cream, Malden Mills, and Nova Chemicals have changed over time. Each of these companies is widely recognized to be engaged in purposeful efforts toward being socially responsible. In the case of both Ben and Jerry's and Malden Mills, company founders and patriarchs have championed such efforts both within and beyond their organizations.

Based on our investigation of these three companies, we have observed that attributes of stakeholder salience shift over a firm's life cycle, and therefore levels of CSR activities change as well. At least for these firms, we also found that power is the primary attribute of stakeholder salience. That is, in order for a firm to engage in purposeful CSR activities, at least one stakeholder pursuing a CSR agenda must possess power to impose such an agenda on management. As the power of such a pro-CSR stakeholder wanes, firms become less and less concerned about CSR as a primary corporate objective. For example, as Ben and Jerry's Ice Cream expanded, and as the company patriarchs' role in managing and financing the company decreased, the firm has become more susceptible to outside pressure to increase company profits at the expense of its historical CSR agenda. In the case of Malden Mills, when the company patriarch lost managerial control subject to bankruptcy, creditors exerted pressure on the financially 
distressed firm to make tradeoffs between increasing profitability and CSR efforts. For Nova Chemicals, the company's participation in CSR efforts appears to be due to the chemical industry's initiation of its "Responsible Care" program. While this program is voluntary, we assert that political and peer pressure (i.e., stakeholder power) for Nova to participate is present. Based on the evidence from our analysis of these three companies, our conclusion is that without power, legitimacy and urgency may not provide sufficient stakeholder salience to promote CSR activities.

This paper is organized as follows. First, we provide reviews of Mitchell et al.'s stakeholder salience theory and the extant literature relating to corporate social responsibility. We then examine both the historical and contemporary efforts of our chosen three companies to engage in CSR activities. Next, we attempt to explain the history of CSR efforts at these companies in light of the pro-CSR stakeholders and their attributes of salience. Finally, we provide some observations based on our review of these three firms' CSR efforts that may help managers and owners of other organizations to maintain CSR agendas in spite of the challenges of corporate growth, financial distress, or the declining influence of a CSR champion.

\section{MITCHELL ET AL.'S STAKEHOLDER SALIENCE THEORY}

Contemporary corporate governance models are typically classified as either shareholder-dominant or stakeholder-dominant models. The shareholder-dominant models employ widespread acceptance in today's business environment. Proponents of this corporate governance model assert that the shareholder is the primary constituent of a firm. The responsibility for management in this system is to maximize shareholder wealth since this governance model incorporates classical principal-agent theory where the manager is an agent of the shareholder principal.

Unlike the shareholder-dominant corporate governance model, the stakeholder approach is broad in nature; it recognizes that other stakeholder groups (e.g., employees, customers, suppliers, communities, and the environment) are important constituents of the business firm. Corporate governance systems using this approach consider both the needs of various consistencies and tradeoffs between the interests of various stakeholder groups (McAlister et al., 2003; Neill et al., 2003).

Even though the literature relating to the importance of multiple stakeholders dates from 1984 (Freeman, 1984), the concept of stakeholder salience is relatively new. Mitchell, Agle, and Wood (1997, p. 854) define stakeholder salience as "the degree to which managers give priority to competing stakeholder claims." In other words, Mitchell et al.'s stakeholder salience theory attempts to define "the principle of who and what really counts." Given the numerous potentially competing stakeholder groups, such a theory is valuable in prioritizing managerial attention. There are three attributes of stakeholder salience inherent in the theory. In particular, Mitchell et al. maintain that managers pay attention to various stakeholder groups based on the power, legitimacy, and urgency of the claims of each group.

The concept of stakeholder power is readily understood. A common description of stakeholder power is such power exists where "one social actor, A, can get another social actor, B, to do something that B would not have otherwise done" (Pfeffer 1981, p. 3). In other words, a stakeholder group possesses power if it is able to impose its will on another, namely management in this context. The second attribute of stakeholder salience is legitimacy. According to Suchman (1995, p. 574), "Legitimacy is a generalized perception or assumption that the actions of an entity are desirable, proper, or appropriate within some socially constructed system of norms, values, beliefs, and definitions." Urgency is the final stakeholder salience attribute. Mitchell et al. define urgency as the degree to which stakeholder claims call for immediate attention. Urgent claims are those that are both time sensitive and of critical importance to a particular stakeholder group.

According to the stakeholder salience theory, power, legitimacy, and urgency are independent attributes. It is thus possible for a stakeholder to have power in the relationship but not have a legitimate or urgent claim on management. Therefore, power by itself is not sufficient for a high degree of stakeholder salience. In the same way, a legitimate claim without power and urgency will possess low stakeholder salience. Mitchell et al. therefore propose that stakeholder salience will be positively related to the cumulative number of stakeholder attributes perceived by 
managers to be present. For example, stockholders frequently receive the attention of managers because stockholders possess both powerful and legitimate claims on the corporation through the private property rights paradigm.

The previously described theory was developed as a general theory of stakeholder salience. Empirical support for this general theory has been documented by Agle et al. (1999). In this paper, we extend previous research by employing the stakeholder salience theory in the specific context of corporate social responsibility.

\section{THE CORPORATE SOCIAL RESPONSIBILITY LITERATURE}

A recent survey published by Hart Research (1999) indicates that the public believes that the modern business firm exists to advance the welfare of groups other than just shareholders. Carroll (1991) and McAlister et al. (2003) suggest that corporate management has at least four areas of responsibility, including economic, legal, ethical, and philanthropic responsibilities. McAlister et al. (2003, p. 9) state that these four dimensions are what "are collectively known as corporate social responsibility." For more comprehensive reviews of the literature concerning the legitimacy of corporate social responsibility, see Snider et al. (2003), Maignan and Ralston (2002), and Freeman and Liedtka (1991).

Accepting CSR as an appropriate agenda is consistent with a multiple stakeholder approach to corporate governance wherein corporate constituencies such as shareholders, employees, customers, government, the community, and the environment are all represented in managerial decision-making criteria. Concerning multiplestakeholder accountability mechanisms, Atkinson et al. (1997), Neill et al. (2003), Gray (1992), and Bloom and Heymann (1986) have all suggested that both financial and managerial accounting models should account for the interests of various stakeholder groups beyond the contemporary accounting model wherein shareholder interests are sacrosanct.

As part of the changing environment in which a multiple-stakeholder view is becoming more accepted, some firms have adopted specific and deliberate CSR agendas. The legitimacy of stakeholder groups such as employees, the environment, and the community(ies) within which a firm operates has been enhanced in recent years by both the changing public views cited above as well as by the theoretical development of multiple-stakeholder corporate governance models. It is likely that purposeful CSR agendas at many firms are both reflexively the result of the changing views referred to above, and are contributing to such changing viewpoints. In this paper, we analyze and the CSR agendas of three companies (Ben and Jerry's Ice Cream, Malden Mills, and Nova Chemicals) in light of Mitchell et al.'s (1997) notions of stakeholder salience.

\section{BEN AND JERRY'S ICE CREAM, INC.}

Ben and Jerry's Ice Cream has a longstanding reputation for CSR. The company's co-founders, Ben Cohen and Jerry Greenfield have championed many environmental and philanthropic activities and these have been well chronicled in the literature (e.g., Carlin, 1995; Dennis et al., 1998). Therefore, only a few of the more prominent examples will be provided here. Ben and Jerry's was one of the first corporations to publish an annual social performance report. This report, now in its $14^{\text {th }}$ year, contains a social audit conducted by an independent third party (Ben and Jerry's, 2002). Ben and Jerry's has traditionally contributed $7.5 \%$ of pretax profits to charitable causes. The chief beneficiary of these charitable contributions is the Ben and Jerry's Foundation. The foundation then selects and provides support for various social and environmental causes. Ben and Jerry's also has a reputation of actively supporting their local Vermont community. They typically pay an above average salary to their employees and they actively support various environmental initiatives. As stated earlier, changing public perceptions regarding the need to address the interests of such constituents along with the principal owners' desire to serve the interests of such alternative stakeholders gave legitimacy to the claims of these stakeholders groups.

A major change in the ownership structure of Ben and Jerry's occurred in August, 2000 when the multinational conglomerate Unilever, Inc. acquired Ben and Jerry's. Subsequent to this acquisition, Cohen and Greenfield's role in the day-to-day operations of the business was drastically reduced. The co-founders have gone 
from owning a majority of the outstanding shares of the corporation to now only having a peripheral role in the running of the business.

Based on the previously described stakeholder salience theory, it is our expectation that the level of corporate social responsibility activities at Ben and Jerry's decreased as a result of the Unilever takeover. This expectation is due to the decreased power of Cohen and Greenfield to pursue an aggressive CSR agenda. In other words, without a powerful stakeholder championing CSR, we expect that the organization's commitment to CSR activities will decrease despite the recognition that the claims of constituents such as employees, the environment, and the communities that Ben and Jerry's Ice Cream supports are legitimate. Armed with this expectation, we undertook an examination of the CSR activities of Ben and Jerry's subsequent to the Unilever takeover to determine if our hypothesis could be supported. The results of our examination reveal some conflicting evidence. However, overall it appears that there has been a reduction in CSR activities at Ben and Jerry's subsequent to the Unilever takeover.

Soon after the ownership change, a CEO with a long-time Unilever background was appointed to oversee the operations of Ben and Jerry's. Cohen and Greenfield were unhappy with this appointment since Unilever decided not to choose their hand-picked candidate for the job. Cohen and Greenfield recommended a candidate who was firmly entrenched in the Ben and Jerry's culture (Smith, 2000). The co-founders at one point publicly expressed questions about whether they would continue their association with the company that was named after them (Burger, 2001).

As stated earlier, Ben and Jerry's is a leader in terms of producing a corporate social responsibility report which includes a social audit. The 2002 social auditor's report (Ben and Jerry's, 2002) to the stakeholders of Ben and Jerry's is extremely informative as to how the culture of Ben and Jerry's has changed since the Unilever takeover. The social auditor's report (Ben and Jerry's 2002, p. 1) states that the company's approach to business is now "more serious and more focused on financial results." In addition, the report reveals that plants were closed and the first large-scale layoffs in the history of the company occurred during 2002. The social auditor's report indicates that Unilever is also undertaking a more focused approach to CSR than occurred under the previous owners. In particular, under the new regime, the number of CSR initiatives has been reduced to the following three: economic and social justice initiatives, environmental issues, and community involvement. Unilever has publicly announced their commitment to maintaining the social mission of Ben and Jerry's Inc. In fact, they have stated that their more focused approach will improve upon the less formal CSR agenda previously employed when Cohen and Greenfield ran and owned the company.

Therefore, based on our analysis of the post-Unilever Ben and Jerry's, it appears that increasing profitability (and hence shareholder value) has become significantly more important subsequent to the takeover. By contrast, many of Cohen and Greenfield's actions appear to have been driven by their social consciousness rather than a desire to enhance shareholder wealth. Even though Unilever has publicly expressed a desire to maintain a high level of CSR, they have in fact reduced the number of CSR initiatives down to three areas. In summary, as stated by the social auditor, even though Unilever strongly advocates the importance of maintaining Ben and Jerry's social mission, the culture of Ben and Jerry's has changed subsequent to the ownership change. The results of our analysis of the Unilever-owned Ben and Jerry's are therefore consistent with the notion that maintaining a high level of CSR activities is difficult without the presence of a powerful stakeholder (or stakeholders in this case) that champions such social causes, regardless of how legitimate the claims of stakeholders benefiting from a CSR agenda might be. Obviously, the effect of the Unilever takeover on CSR activities at Ben and Jerry's will continue to unfold over time; however, it is our contention that the trend of reduced CSR activities that has occurred over the last two or three years will likely continue in the future.

\section{MALDEN MILLS, INC.}

Malden Mills is a textile manufacturing company based in Lawrence, MA. The company is well known for CSR, especially with respect to employees' interests. In fact, the company's patriarch, Aaron Feuerstein, is a CSR champion in the area of employee issues. There have been numerous stories both on television (60 Minutes) and in business periodicals regarding the aftermath of a massive plant fire that occurred to Malden Mills' Lawrence plant in 1995. Even though the plant was destroyed and production ground to a halt, Feuerstein continued to pay his 
employees during the period of time that the plant was being rebuilt. This action demonstrated an extreme sense of loyalty to both the Malden Mills employees and to the city of Lawrence. There were many less expensive alternatives available to Mr. Feuerstein such as (1) not rebuilding the plant at all, (2) temporarily laying off employees until the plant was rebuilt, or (3) following the lead of others in the textile industry and relocating operations to the south where costs would be lower. However, Aaron Feuerstein chose the path that was most beneficial to his employees and community over a path that might have led to greater profitability.

Relating the Malden Mills example to Mitchell et al.'s stakeholder salience theory, we maintain that the claims of the company's employee and community stakeholder groups were legitimate. This legitimacy is based on the general public's perceptions regarding the increasing importance of multiple stakeholder groups, and Mr. Feuerstein's desire to preserve the interests of his employees and the community in which the company resides. In addition, the employees' and community's claims to corporate resources were also urgent as a result of the devastating fire in 1995. Therefore, in the case of Malden Mills, it would be consistent with Mitchell et al.'s theory to suggest that the company's employees and community possessed the stakeholder salience attributes of legitimacy and urgency, and as the company owner, Aaron Feuerstein possessed the power to pursue the employees' and community's interests.

Subsequent to the fire, Malden Mills experienced severe financial distress. The financial hardships were from two main sources: (1) lost sales and reconstruction costs resulting from the fire and (2) several warm winters resulted in a decreased demand for fleece, which was the company's major product line. Due to these events, Malden Mills incurred large amounts of debt and eventually declared bankruptcy in 2001. In October, 2003 the company announced that it would emerge from bankruptcy having reduced its debt from approximately $\$ 170$ million to about $\$ 80$ million (Associated Press, 2003). However, Feuerstein will no longer have day-to-day control of the company as CEO. As a result of the bankruptcy, company creditors will now control the board of directors and Feuerstein only owns about $5 \%$ of the company stock.

Based on Mitchell et al.'s stakeholder salience theory, we expect that the level of CSR at Malden Mills decreased as a result of the ownership change that occurred subsequent to the bankruptcy filing. This expectation is due to the decreased power of Aaron Feuerstein to actively pursue a CSR agenda. In addition, since the creditors now own a controlling interest in the company and dominate the board, their salience (power) has increased. Thus without a powerful stakeholder championing CSR, as was historically the case when Mr. Feuerstein was in control, we expect that the organization's commitment to CSR activities will decrease.

We examined the post-bankruptcy Malden Mills, Inc. in an attempt to determine how the level of CSR changed subsequent to the restructuring and ownership change. Unfortunately, a definitive answer to this question cannot be given at this time due to the recency of the company's emergence from bankruptcy protection. However, it is obvious that Feuerstein is concerned about the negative impact that the creditor-led board of the newly restructured Malden Mills may have on its community and employees. In fact, Feuerstein has stated that he is in the process of attempting to raise enough money to buy a controlling interest back from the creditor group. The stated reason for this desire to regain control is that such a move "is essential if the company is to remain in the economically distressed city of Lawrence (MA)." (Associated Press, 2003). Therefore, while it is too early to fully assess the impact of the reorganized company on its community and employee stakeholder groups, it is obvious that the company patriarch fears the new owners may shut down the plant in Lawrence and displace numerous employees and cause severe financial hardship on the community of Lawrence, MA. Such an action might occur if the creditor-led board puts the goal of increasing profitability ahead of the concerns of the community of Lawrence and the employees of Malden Mills. Therefore, even at this early stage in the life of the post-bankruptcy Malden Mills, it appears that CSR-related activities will be reduced unless Aaron Feuerstein is able to regain the power necessary to successfully champion such efforts.

\section{NOVA CHEMICALS COMPANY}

As a member of the American Chemistry Council (ACC, formerly known as the Chemical Manufacturers Association (CMA)), Nova Chemicals participates in an industry-wide CSR initiative and reporting program called Responsible Care (RC). Nova was chosen for examination because they have been participants in the RC program 
from its inception in the United States in 1989 and because their Responsible Care annual report is easily accessible to the general public through their website. In this Responsible Care annual report, the company reports environmental and health and safety metrics, including variances between actual performance numbers and predetermined organizational goals, and highlights programs of the company that benefit the communities within which they operate.

King and Lenox (2000) suggest that the CMA initiated the RC program in 1989 in response to public concerns and declining opinions about the chemical industry due to abuses that occurred during the 1980s such as the Union Carbide/Bhopal tragedy. King and Lenox (2000, p.699) also state that the purpose of the RC initiative was "two-fold: to improve the environmental and safety performance of CMA members and to thereby improve public perception of the industry." For a more comprehensive description of the RC program, see Yosie (2003) and King and Lenox (2000).

Once again, we maintain that Nova's CSR agenda is legitimate due to the increasing public perception that the claims of constituents such as the environment and the community in which a firm operates are important for management to consider when making decisions. Also, the ACC's emphasis on the importance of the claims of such stakeholders via the creation and implementation of the RC program serves to increase the stakeholder salience legitimacy attribute of the environment and community stakeholder groups.

In contrast to the previous companies that are used as examples in this paper (i.e., Ben and Jerry's Ice Cream and Malden Mills), Nova has not experienced a recent change in ownership/control that threatens its participation level in CSR activities. Rather, the event in the life of the company that potentially caused a change in corporate social responsibility activity is the creation of the chemical industry's RC program back in the late 1980s. Based on Mitchell et al.'s stakeholder salience theory, we expect that the level of corporate social responsibility at Nova Chemicals increased as a result of the industry-wide RC initiative. In addition to the legitimacy of the claims of the various stakeholder groups described above, this expectation is due to the power that the ACC possesses through (1) the peer-pressure that it is able to exert on its members to participate in and emphasize the RC program (King and Lenox, 2000; Yosie, 2003), and (2) the potential for an industry and the firms of which it consists to avoid additional government regulation by practicing self-regulation (Yosie, 2003).

While the RC program is typically thought of as being voluntary, in actuality the ACC requires that each of its members participate in the program (King and Lenox, 2000). Therefore, if a company wants to be an ACC member in good standing, the RC program is mandatory. Industries with high visibility and the potential for environmental and public harm such as the petroleum and chemical industries have long faced a good deal of governmental scrutiny. They also face the potential threat of additional intervention into their operations should the public demand that their political representatives impose new regulation as the result of some crisis or scandal. We therefore contend that one reason why Nova participates in its articulated CSR program is because powerful constituencies such as the ACC, the public, and the state want it to do so.

Our investigation of the company (which included, among other things, a phone interview with a company executive and an examination of the company's Responsible Care annual report), revealed that Nova is currently placing an emphasis on CSR activities throughout the organization. While it is difficult to obtain objective data regarding the level of CSR activity at Nova prior to the chemical industry's initiation of RC, it is apparent that Nova's level of corporate social responsibility reporting has greatly increased over the years. As stated earlier, the company currently posts a copy of their most recent RC annual report on their website and this report is readily accessible to all interested parties. In addition, Nova did not engage in a purposeful and systematic attempt at measuring and reporting corporate social responsibility before the CMA initiated its RC program in 1989. Therefore, it appears that Nova has greatly increased both its actual participation in CSR and its CSR reporting in the years subsequent to the start of the $\mathrm{RC}$ program. While we did not conduct a detailed investigation of other chemical companies, our expectation would be that all members of the ACC have increased their CSR activities as a result of their participation in the industrywide RC program. 


\section{LIMITATIONS AND CONCLUSIONS}

While we assert in this paper that the primary attribute of stakeholder salience driving the CSR of these three companies is the power that the historical and contemporary CSR proponents possess, we must also point to the possibility that management has pursued a CSR agenda at these three companies in order to promote the economic interests of their shareholders. Specifically, we acknowledge that the previous owners of Ben and Jerry's Ice Cream (Ben Cohen and Jerry Greenfield) as well as the current owner (Unilever) benefit financially from the perspective that the company portrays itself as being socially responsible through its marketing strategies. Also, it is generally accepted that Aaron Feuerstein enjoyed a tremendous degree of employee loyalty and productivity due to his proemployee image. Finally, Nova Chemicals states explicitly in its 2002 Responsible Care Annual Report (Nova Chemicals, 2002) that one of the primary reasons why it participates in the RC program is because "Responsible Care makes good business sense." Mitchell et al. (1997) suggest that management pursues corporate shareholders' agendas such as the profit motive because shareholders enjoy salience from both legitimacy and power.

Also, our sample size of three companies is small and may suffer from a selection bias. Given this potential research limitation, we believe that the reader can benefit from seeing the effects of significant internal and external events on the CSR agendas of these three companies. Future studies that examine additional companies are needed before any generalizations may be made, but the evidence collected from these three companies suggests that power is the most important attribute of stakeholder salience in the specific case of CSR.

From our examination of these three companies' CSR activities over time, it appears that at least one proCSR constituent must possess the power to direct management to pursue the interests of various stakeholder groups via a CSR agenda. While the stakeholder salience attribute of legitimacy was (is) present in all three of the cases we examined, it was (is) insufficient to sustain a constant or increasing level of CSR activities within each firm. In the case of Malden Mills, both the legitimacy and urgency of employees' and the community's claims were (are) not enough to carry such efforts.

\section{REFERENCES}

1. Agle, B., R. Mitchell, and J. Sonnenfeld. (1999). Who Matters to CEOs? An Investigation of Stakeholder Attributes and Salience, Corporate Performance, and CEO Values, Academy of Management Journal 42 (5), 507-526.

2. Associated Press. (2003). Fleece Maker Malden Mills Emerges From Protection, available at http://foxnews. com /story/0,2933,100430,00.html.

3. Atkinson, A., J. Waterhouse, and R. Wells. (1997). A Stakeholder Approach to Strategic Performance Measurement, Sloan Management Review 38, 25-37.

4. Ben and Jerry's. (2002). Social and Environmental Assessment 2002, available at http://www.benjerry .com/our_company/about_us/environment/social_audit/final_socialaudit.pdf.

5. Bloom, R., and H. Heymann. (1986). The Concept of 'Social Accountability' in Accounting Literature, Journal of Accounting Literature 5, 167-182.

6. $\quad$ Burger, K. (2001). Rude Awakenings, Insurance and Technology 26 (2), 4-7.

7. Carlin, P. (1995). Will Rapid Growth Stunt Corporate Do-Gooders? Business and Society Review 93, 36-43.

8. Carroll, A. (1991). The Pyramid of Corporate Social Responsibility: Toward the Moral Management of Organizational Stakeholders, Business Horizons 34 (4), 39-48.

9. Dennis, B. and C. Neck. (1998). The Scoop on Ben \& Jerry's Inc.: An Examination of Corporate Social Responsibility, Journal of Managerial Psychology 13 (5/6), 387-393.

10. Freeman, R. (1984), Strategic Management: A Stakeholder Approach, Prentice-Hall, Englewood Cliffs, NJ.

11. Freeman, R. and J. Liedtka. (1991). Corporate Social Responsibility: A Critical Approach, Business Horizons 34 (4), 92-98.

12. Gray R. (1992). Accounting and Environmentalism: An Exploration of the Challenge of Gently Accounting for Accountability, Transparency, and Sustainability, Accounting, Organizations, and Society 17 (5), 399426. 
13. Hart Research Associates. (1999). The Polling Report, Inc., and Polling/Sponsoring Organizations, Poll conducted for Shell Oil, March 16-20, 1999, available at http://www.pollingreport.com/business.htm.

14. King, A. and M. Lenox. (2000). Industry Self-Regulation Without Sanctions: The Chemical Industry's Responsible Care Program, Academy of Management Journal 43 (4), 698-716.

15. Maignan, I. and D. Ralston. (2002). Corporate Social Responsibility in Europe and the U.S.: Insights from Businesses' Self-presentations, Journal of International Business Studies 33 (3), 497-514.

16. McAlister, D., O. Ferrell, and L. Ferrell. (2003). Business and Society: A Strategic Approach to Corporate Citizenship, Houghton Mifflin, Boston, MA.

17. Mitchell, R., B. Agle, and D. Wood. (1997). Toward a Theory of Stakeholder Identification and Salience: Defining the Principle of Who and What Really Counts, Academy of Management Review 22 (4), 853-886.

18. Neill, J., O. Stovall, and D. Perkins. (2003). The Balanced Scorecard: A Multiple Stakeholder Perspective, Journal of Accounting and Finance Research 11 (5), 58-68.

19. Nova Chemicals. (2002). Responsible Care Annual Report, available at http://www.novachem.com/ 06_community/rc_annual_03/01_whatis_2.htm.

20. Pfeffer, J. (1981). Power in Organizations, Pitman, Marshfield, MA.

21. Smith, G. (2000). A Famous Brand on a Rocky Road, Business Week, December 11, 54-57.

22. Snider, J., R. Hill, and D. Martin. (2003). Corporate Social Responsibility in the $21^{\text {st }}$ Century: A View from the World's Most Successful Firms, Journal of Business Ethics 48 (2), 175-187.

23. Suchman, M. (1995). Managing Legitimacy: Strategic and Institutional Approaches, Academy of Management Review 20, 571-610.

24. Yosie, T. (2003). Responsible CARE at 15 Years, Environmental Science \& Technology 37 (21), $400-406$. 